\title{
A Durkheimian Reading of Sarah Kane's 4.48 Psychosis
}

$$
\text { By }
$$

\author{
Dr. Mahmoud El Bagoury \\ Lecturer of English Literature \\ Faculty of Arts, Suez University
}

DOI: $10.21608 /$ jfpsu.2021.68760.1057 


\title{
A Durkheimian Reading of Sarah Kane's 4.48 Psychosis
}

\begin{abstract}
This paper aims at exploring the multi-layers of suicide in Sarah Kane's play 4.48 Psychosis (2000) in the light of Emile Durkheim's identifications of suicide: egoistic suicide, altruistic suicide, anomic suicide, and fatalistic suicide. The play encompasses these kinds of suicide through the portrayal of a hospitalized patient battling with her psychotic disorders and suicidal thoughts. Egoistic suicide is demonstrated through the patient's social alienation from the mainstream of society and her submersion into a state of egoism. Altruistic suicide is depicted either through the patient's view of suicide as a window overlooking infinity where the ego should be situated beyond life itself or through her inability to cope with her mental illness. Anomic suicide takes place when the patient falls into the abyss of frustration, despair, vulnerability, and anomy because of society's indifference to her feelings, passions, and organic necessities. Fatalistic suicide is manifested through her suffocation by the overregulation of society represented by the oppressive, uncaring medical system. The disintegration of the human mind of the depressed patient is poignantly divulged through the employment of the stream of consciousness. Rarely do we find dialogical parts except the conversations between the patient and the therapist. Kane does not designate characters throughout the play as though she desires to grab the readers into the labyrinth associated with suicidal thoughts.
\end{abstract}

Keywords: Durkheim, psychotic disorders, egoistic suicide, altruistic suicide, anomic suicide, fatalistic suicide. 


\section{قراءة دوركايمية لمسرحية "ذُهان 4.48" لسارة كين}

المستخلص

يهدف هذا البحث إلى استكثاف الأشكال المُتعددة للانتحار في مسرحية "ذهان

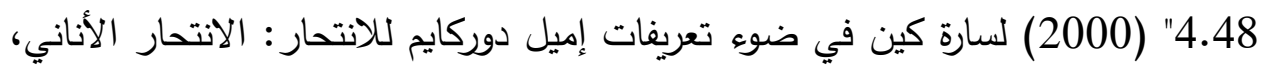

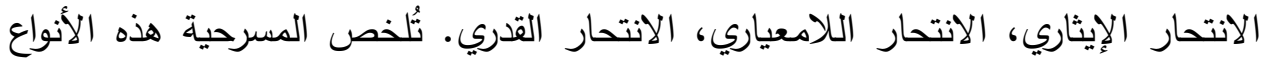

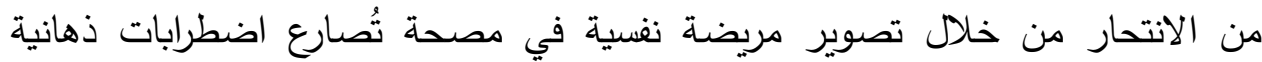

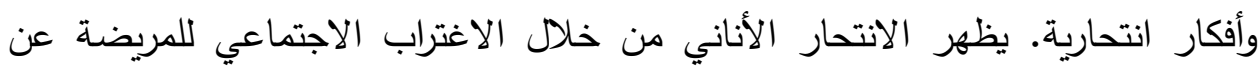

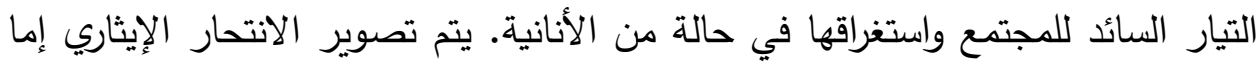
من خلال رؤية المريضة للانتحار كنافذة تُطل على الأبدية حيث يجب ين أن تكون أناها خارج الحياة نفسها أو من خلال عدم قدرتها على التعامل مع مرضها العقلي. يظهر الابله الانتحار اللامعياري عندما تقع المريضة في هاوية الاحباط واليأس والوهن وفقدان التواصل بسبب عدم اكتراث المجتمع تجاه عواطفها ومشاعرها وضروراتها العضوية. يتجلى الانتحار القدري من خلال شعورها بالاختناق بسبب المبالغة في التتظيم المجتمعي

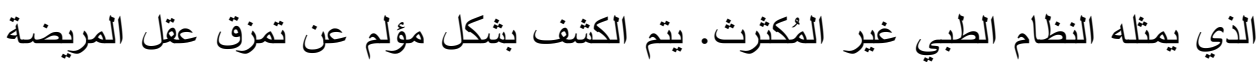

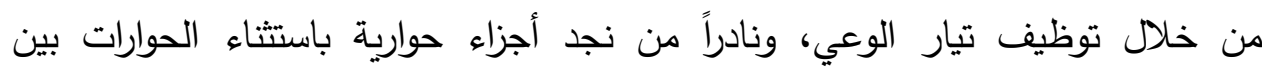

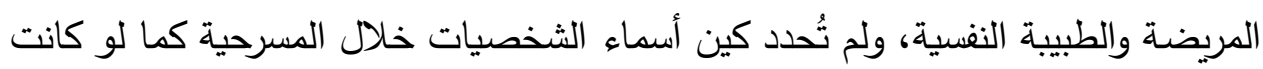
لديها الرغبة في جذب القراء إلى المتاهة المرتبطة بالأفكار الانتحارية.

الكلمات المفتاحية: دوركايم، اضطرابات ذهانية، الانتحار الأناني، الانتحار الإيثاري، الانتحار اللامعياري، الانتحار القدري. 
Dr. Mahmoud El Bagoury

\section{Introduction}

Sarah Kane is a notable English playwright who was raised as a Christian but she converted into Evangelism at the age of seventeen, and afterwards she rejected faith completely. She was also noted for her roles as an actress. She had a very independent spirit and this is apparent in her plays through the portrayal of characters who are preoccupied with self-definition, self-awareness, self-authentication, and self-fulfillment, but their journeys towards authentic selfhood coerce them to embrace alienation, anxiety, nihilism, and suicidal thoughts. However, she stopped acting to free herself from the overregulation imposed by directors. Kane was bitterly tormented by the idea of stardom because she regarded it as a kind of violence. Two years before committing suicide, she was hospitalized because of severe depression, anorexia, mental breakdowns, and suicidal thoughts till she put her thoughts into force at the age of 28. Kane's last moments at the bathroom where she committed suicide has been overshadowed in a scene of her play Blasted in which Cate, a young girl who suffers from mental breakdowns, cries out in despair while having a bath, saying: "Looks like there's a war on" (Kane, Complete Plays 33).

Kane is known primarily for her plays: Blasted (1995), Phaedra's Love (1996), Cleansed (1998), Crave (1998), and 4.48 Psychosis (2000). Due to her unique dramaturgy, she was supported by the most prolific English playwrights of her time such as Harold Pinter and Edward Bond. She is labeled as the most significant postwar English playwright, and her theatre is labeled as the Theatre of Extremes because her characters spend their lives in search of ultimate truths, but unfortunately they face obstacles which push them to question and rethink themselves and the standards of human experience. When they finally come to the conclusion that human existence will not provide absolute truths and inner peace for them, they fall into the void of hollowness and incompleteness. In writing, Kane mimics Samuel Beckett and Antonin Artaud, two playwrights 
whose characters gain insight from suffering and pain. Her inspiration by absurdist dramatists, argues Graham Saunders, propels her to charge her plays with "extreme and brutal actions" (Saunders 22). Saunders goes one step further when he categorizes Kane as one of the most prominent playwrights known as "the New Brutalists" (4). Her affinity with Artaud can best be understood from her willingness to espouse his metaphysical concept of cruelty as a tool used by characters with psychological disorders to commit suicide. Artaud once declared, "I use the word cruelty in the sense of hungering after life, cosmic strictness, relentless necessity, in the Gnostic sense of a living vortex engulfing darkness, in the sense of the inescapably necessary pain without which life could not continue" (Artaud 80). Artaud's argument expounds how far Kane takes cruelty and violence to be an outlet for the fragmented individual to free himself from the chaotic life when he discovers its futility and loses any hope for salvation except violence against himself by committing suicide.

Most importantly, Kane is an in-yer-face dramatist whose characters live under unbearable conditions that they might appear as tragic heroes torn between their inner thoughts, feelings, beliefs, and the suffocating fabric of society, or as Aleks Sierz points it out: "Inyer-face theatre always forces us to look at ideas and feelings we would normally avoid because they are too painful, too frightening, too unpleasant or too cute" (Sierz, In-Yer-Face Theatre 6). From this angle, Kane's drama thunderously shakes the inside of her characters, and this thunderous shake triggers a sense of nausea and discomfort that they remain to suffer from psychic torture and glamorizing cruelty which drive them to take violence as a defense mechanism whether against society or even against themselves. Sierz furthers his argument by insisting that the iconic body of Kane's drama belongs to the modern drama which "threatens to violate that sense of safety" (6). For example, Kane's Blasted is written in a Beckettian style. The play's affinity with Beckett's Waiting for Godot is quite apparent. The last scene of the play 
portrays Cate who guides the blind man Ian, thereby resembling the scene in which Lucky guides his blind master Pozzo in Waiting for Godot. Both Cate and Ian and Lucky and Pozzo are trapped in a Beckettian space and time, but these depersonalized characters cannot escape the unbearable conditions which distort their existence and empties it of any meaning. Unlike Beckett's characters, Kane's choose to take action instead of falling into the prison of inaction in an attempt to jump over the deformed reality and touch the world of infinity even by committing suicide.

By extension, Martin Crimp argues that Kane, like Harold Pinter and Samuel Beckett, has transformed theatre into a mental space: "In the $20^{\text {th }}$, Pinter and Beckett transformed it into a mental space, which some writers (the Kane of Crave and 4.49 Psychosis) continued to explore" (qtd. in Sierz, The Theatre of Martin Crimp 140). Kane's characters thus reject personal identifications and ontological certitude: they remain to suffer from an existential void stemming mainly from their basic awareness of the threat of depersonalization. Out of their submersion into uncertainties and the existential anguish which brutally pursue them, these characters are preoccupied with the essence of man's position in the world and inquiry for absolutism. From this perspective, Kane's theatre is categorized as a post-dramatic theatre which, as Sean Carney points out, is marked by "aesthetic disruption" which "deliberately frustrates coherence and continuity" (Carney 276). In other words, Kane's characters are fascinated by the disruptive elements of the world as they question the basic issues of morality, good, evil, the existence of God, and their relationship to each other, but they fail to come eventually to objective realities which might erect a sanctuary of inner peace for them, but rather provides extreme uncertainty which shatters all their beliefs in themselves and in social norms respectively.

For Kane, the self-inflicted individuals lose their sense of their physicality that most of her characters are haunted by invisible men, evil spirits, and birds of prey. Because they are absolutists and truth- 
seeking, they undertake the responsibility of rejecting rationalization by embracing the extreme aesthetics of risk or insanity and breaking taboos. Sierz touches a raw nerve when he asserts that postdramatic theatre is "always marking a point of no return" (Sierz, In-Yer-Face Theatre 209). Kane's theatre, thus, is a theatre of disruption and disintegration that dialogue itself takes the shape of a Beckettian style through the use of monologue, repetition, and long silences to mirror the lack of the notions of coherence or central self.

The present study reflects on the identifications of suicide proposed by the French sociologist Emile Durkheim in order to investigate how suicidal aesthetics are contextualized in Kane's 4.48 Psychosis which tells the life story of a depressive patient who is torn between sanity and insanity, reality and imagination, consciousness and hyperconsciousness. The patient's speeches swift from psycho-monologues when she addresses her alter-ego to dialogues when she addresses her therapist or her lover, but the therapist and her lover sometimes merge into one person because of the mental disorders by which she is lethally haunted. According to Clare Wallace, the breakdown of language in 4.49 Psychosis takes the form of a semi-Beckettian "verbal despair" (Wallace, "Sarah Kane" 7). The psychological disorders and distressing despair, however, drive the patient to commit suicide with the close of the play. Therefore, Annabelle Singer argues that 4.48 Psychosis is a "70 minute suicide note" (Singer 160). In her interview with Dan Rebellato, Kane comments on her driving force behind writing 4.48 Psychosis, saying: "I'm writing a play called Four Forty-Eight Psychosis. It's about a psychotic breakdown. And what happens to a person's mind when barriers that distinguish between reality and different forms of imagination completely disappear" (Kane, "Interview by Dan Rebellato" 19). Kane unravels inner conflicts through throwing the depressed patient into a psychological void inside an insane mind, but the utterances of the patient is the magnifying glass whereby the reader can observe her deep psychotic disorders. Throughout the play, the patient's mental disintegration 
unfolds itself most clearly through psycho-monologues and fictional dialogues, thereby illustrating a mind filled with delusions and hysterical intrusions. Above all, the patient is not given a name. The anonymity of the patient is intended by Kane to indicate the universality of the patient's psychotic disorders, including selfhatred, schizophrenia, depression, delusions, and hallucinations.

In his seminal book Suicide: A Study in Sociology, Durkheim proposes four kinds of suicide: egoistic suicide, altruistic suicide, anomic suicide, and fatalistic suicide. Egoistic suicide takes place when the individual becomes socially alienated from the mainstream of society and strongly indulged into a state of egoism. Altruistic suicide occurs when the ego is besieged by intense altruistic motives or by its inability to cope with ailments. Anomic suicide emerges when the individual falls into the abyss of frustration, despair, hopelessness, vulnerability, and anomy. Fatalistic suicide occurs when the individual is agonizingly suffocated by the overregulation of society.

For Durkheim, egoistic suicide and altruistic suicide are symptoms of the individual's rejection of the way he is structured into society. He explains that egoistic suicide is a state of egoism which emanates from "excessive individualism" (Durkheim 168). When the individual loses "the mutual moral support" (168), represented by the interchange of his ideas and feelings with the mainstream of society, he begins to face so deep psychological troubles which force him towards egoistic suicide, or as Durkheim diagnoses it: "The more the family and community become foreign to the individual, so much the more does he become a mystery to himself, unable to escape the exasperating and agonizing question: to what purpose?" (171). Put differently, egoistic suicide, notes Durkheim, springs from "man's no longer finding a basis for existence in life" (219). Egoistic suicide, therefore, takes place when the individual feels that his life has no purpose justifying its permanence, since nothing can grant him courage to live, act, and 
struggle and all the trials end eventually in nothing, or what Durkheim calls "a minimal existence" (172). This minimal existence springs from the moral and ethical disintegration of society and accordingly gives rise to currents of severe depression that the individual, who is originally a social being in need to social forms to satisfy his needs and maintain his equilibrium, becomes "a ready prey to suicide" resulting basically from torrents of individualism and egoism (173).

Durkheim divides altruistic suicide into two kinds: optional altruistic suicide and obligatory altruistic suicide. Optional altruistic suicide is "the state of the ego living its own life and obeying itself alone....Altruism leads more directly and more violently to suicide....The individual kills himself purely for the joy of sacrifice" (180-81). Put another way, he maintains that in optional altruistic suicide the individual seeks to be integrated into a hyper-existence situated beyond life itself. Thus, he is haunted by an infinite desire to "strip himself of his personal being in order to be engulfed in something which he regards as his true essence....He must therefore consider that he has no life of his own. Impersonality is here carried to its highest pitch; altruism is acute" (183). He adds that altruistic suicide is sometimes obligatory if the individual cannot cope with a psychotic disorder such as insanity or schizophrenia or depression or anxiety.

Anomic suicide is the result of the individual's attempt to break away from the collective conscience of society to live his own feelings and passions, thinking that society will accept his newfound inner pourings. Durkheim avouches, "Men generally have the desire for self-instruction only in so far as they are freed from the yoke of tradition" (116). He furthers his argument when he notes that when the social norms of society are distorted in the mind of the individual, he has to "reconstruct a conscience by its means" (124), but the newly-established conscience might result in so unbearable troubles, suffering, and anomy because society begins to regard the 
individual as a persona-non-grata. For Durkheim, anomic suicide springs mostly from society's indifference to the passions and feelings of the individual, or what he calls the "organic necessities" such as love, care, warmth, and sexual impulse (233). In a sense, he avers that man has a hidden desire to undergo "the experiences of love" and to live "the life of a Don Juan" (234). When the individual fails to fulfill such desires, he falls into what Durkheim calls "sexual anomy" which creates fragmentation between body and soul that the individual senses that his life is no longer worth living (237).

According to Edward A. Selby et al., fatalistic suicide takes place "when the moral regulation of a society is extreme. This form of suicide, according to Durkheim, would take place in an overly oppressive society that controls most aspects of individual life, and suicide is essentially a release from living such dismal existence" (Selby et al. 290). Kane's 4.49 Psychosis encompasses this cluster of suicidal identifications and it is within these aesthetics of suicide that this study is contextualized.

\section{Egoistic Suicide}

In 4.48 Psychosis, egoistic suicide is apparent through the patient's submersion into uncertainties about her own existence and the value of life. Throughout the play, she questions her own minimal existence and the shameful self-image by which she is recurrently haunted. She tries to piece together the debris of her existence, but she finds it impossible to derive a meaningful code from such a chaotic world. More specifically, the play merely portrays the patient's inner chaos, a devastating chaos which stiflingly coats her fragmented ego. Like Albert Camus' Sisyphus, she finds herself face to face with a burden to wring a measure of equilibrium in an unbalanced world. While she is trying to solve things rationally and empirically using a merciless consciousness, she comes to the conclusion that the world is governed by a deity whose mysteriousness and anonymity drive her to what Maurice 
Nadeau calls "divine malediction" (Nadeau 34), a concept associated with Franz Kafka's view of a world devoid of mercy and safety. Due to her failure in comprehending the world in its totality, the patient falls prey to skepticism about the world and even about her identity that she suffers from "corrosive doubt" and "futile despair" (Kane, Complete Plays 219). This doubt can best be seen as a result of her newfound nihilism and atheism as she describes herself as "the child of negation" (239). She is wherefore haunted by delusions that she "believes consultant in the antichrist" (229).

Sierz rightly observes that the patient's fragmented notion of the ego emerges "only through the acts of interpretation and identifications by means of which we feel for others" (Sierz, "Sarah Kane" 115), or as the patient puts it in the play: "I think that you think of me the way I'd have you think of me" (Kane, Complete Plays 243). Metaphorically, the blurred ego of the patient looks like a fog of weariness and troubles, and this incomplete ego and uncertainty about oneself is what drives her to cry out in despair: "I am a complete failure as a person/ I am guilty/ I am being punished/ I would like to kill myself" (206). By analogy, the patient's obsessive desire to kill herself recalls the following conversation between the enigmatic characters A and B in Kane's Crave:

A: What do you want?

B: To die. (Kane, Complete Plays 155)

The patient's fragmented ego extends even to her physicality: "My hips are too big/ I dislike my genitals" (207). It extends even to others: "I gassed the Jews, I killed the Kurds, I bombed the Arabs" (227). This self-hatred combined with misanthropy can be attributed to the demise of the ideal ego which has been shattered forever due to severe psychotic disorders. The push and pull between the broken ego and the ideal ego forces her to fall into excessive individualism out of being torn between perfection and imperfection, a state which can suffocate the self that she finds no outlet except suicide. Besides, 
her sense of self-hatred is heightened when her self-image is elaborated in the form of a painting facing the wall: "It is myself I have never met, whose face is pasted on the underside of my mind" (245). As a result, she has a semi-Beckettian view of the human condition that the future holds nothing for her: "I am sad/ I feel that the future is hopeless and that things cannot improve/ I am bored and dissatisfied with everything....This is not a world in which I wish to live" (206-209). The patient's argument recalls Kane's elaboration of her enigmatic characters' dislike of life in Crave:

C: Why did I not die at birth?

$\mathrm{M}$ : Come forth from the womb.

B: And expire. (Kane, Complete Plays 193)

It is not surprising thus that the patient regards life as "this dreary and repugnant tale of a sense interned in an alien carcass" (214). This blurred view of human existence, however, throws the patient's ego into an existential void filled with a sense of incompleteness, the bottomless abyss of possibilities having nothing to cling to, interpersonal loneliness, and internal alienation. The existential void which encapsulates her ego brings about a split between her body and her soul, a split which brutally devours her sense of selfsameness. For that reason, she raises the following dialectical question: "Do you think it's possible for a person to be born in the wrong body?" (215). This split can best be understood from her utterance: "Here am I/ and there is my body" (230). These words are illustrative of the fragmentation which haunts her ego every, every minute. This "dissociation of selfhood", to use Graham Saunders' terminology, is the magnifying glass which obviously reflects the patient's "separation of mind and body" (Saunders 116). Under such a prism, Judith Butler notes that this split elucidates the patient's rejection of the social forms "by which we are recognized as human" (Butler 2). Significantly, this dissociative fugue shatters the patient's sense of completeness that she senses that her ego is persecuted by a bitter sense of shamefulness: "Shame shame shame/ Drown in your 
fucking shame" (Kane, Complete Plays 209). Hence, she complains of "discordant anxiety/ which roars in [her] soul" (215), and therefore she yearns for her sweet self which she calls her "loved one" to which she wishes to sing a song: "A song for my loved one, touching her absence/ the flux of her heart, the splash of her smile" (215).

Following Lacanian terminology, the split between the imagined ego and the experienced ego is what drives the patient to give voice her wish "to become who I already am" because she visualizes her ego as incomplete and divided (212). Added to this, the patient's overwhelming desire to have a complete and undivided ego is reinforced by the therapist when the latter tells her that "there is an objective reality in which my body and mind are one" (209). Nevertheless, she finds it impossible to achieve such an objective reality and consequently she declares: "I have lost interest in other people/ I can't make decisions/ I can't eat/ I can't sleep/ I can't think/ I cannot overcome my loneliness/ my fear, my disgust/ I am fat/ I cannot live/ I cannot love" (207). Hereupon, the "psychiatric voice of reason" convinces her to believe that "body and soul can never be married" except through suicide (212). Indeed, the aforementioned verification of the psychiatric voice of reason regarding the inevitability of self-division pushes her to the abyss of insanity more and more, an abyss which encompasses egoistic suicide.

Accordingly, she comes to the conclusion that the objective reality in which body and soul are one is nothing but nothingness which the individual can be in conformity with through turning his existence into an inanimate state through committing suicide, thereby doing away with his unbalanced ego which distorts his existence. In other words, she regards suicide as a gateway to come much closer to an objective reality to touch which she calls her "essential self" (229). The patient's following confession is quite telling in this regard: "I have resigned myself to death this year/ 
Some will call this self-indulgence" (208). What the patient calls "self-indulgence" is compatible with what Durkheim calls a state of egoism which can drive the individual to commit suicide. Above all, this self-indulgence propels her to nothingness as she declares: "The only thing that's permanent is destruction/ we're all going to disappear" (240).

It becomes clear here that the split between the imagined ego and the experienced ego can never be filled that the patient asserts: "Nothing can extinguish my anger/ and nothing can restore my faith.... Nothing can fill this void in my heart" except suicide (209219). So, she insists that "after 4.48 I shall not speak again" (213). Unquestionably, the patient's desire to unite with her essential self can best be understood from Sigmund Freud's concept of egoinstincts which fuel the individual's yearning to "restore the inanimate state" (Freud 38). Existentially speaking, the split of the patient's ego triggers ontological disturbances which flung her into schizophrenia, or as Frederic Jameson points it out: "Schizophrenic experience is an experience of isolated, disconnected, discontinuous material signifiers which fail to link up in a coherent sequence. The schizophrenic thus does not know personal identity in our sense" (Jameson 119). Significantly, the patient's self-division in 4.48 Psychosis is reminiscent of the enigmatic character $\mathrm{C}$ in Kane's Crave. C once declares: "That's me. Exist in the swing. Never still, never one thing or the other, always moving from one extreme to the furthest reaches of the other" (Kane, Complete Plays 194).

Technically, the long spaces between lines throughout the play are reflexive of the void which ruptures the patient's ego. Even the structure of the play mirrors the mental distractions of the patient as there is no cohesiveness or even coherence. It seems as though Kane wishes to keep the patient in the dark about her egoistic motivations, leaving behind an atmosphere of menace as if she is trapped in the fragmented structure of the play which looks like a prison, thereby reflecting on the ego as a prison filled with anguish, lethal wounds, 
and pointlessness of her life. Rarely do we find stage directions in the play, and this indicates that the whole reality has been distorted within the patient's ego.

\section{Altruistic Suicide}

Altruistic suicide in 4.48 Psychosis takes the two forms proposed by Durkheim: optional altruistic suicide when the patient regards suicide as an embracing light or even a moment of illumination or epiphany and obligatory altruistic suicide when the patient becomes unable to cope with her mental illness. The patient's choice of the timing 4.48 to kill herself is symbolic of the crack of dawn, a time when "clarity visits" (Kane, Complete Plays 242). Her last words "please open the curtains" are indicative of an emancipatory escape from the ruthless claws of human existence which is marked by anarchy and mysteriousness to the Kingdom of God which is agog with euphoria, ecstasy, restfulness, and pleasure. In this context, suicide turns out to be an absolute, satisfying, praiseworthy, allencompassing experience for the patient as though it is a great achievement she has to accomplish or a sacrifice she has to offer. Following Durkheimian terminology, Kane regards suicide as an appropriate medium through which the patient can build up a communion with the world of infinity and absolute truths. This is made clear when the patient describes the time of suicide 4.48 as a "happy hour" (242). Likewise, in Kane's Blasted, Ian laughs "hysterically" while he is "dying with relief" (Kane, Complete Plays 59-60), and in Phaedra's Love, Hippoltytus's reaction to his death is quite similar: while breathing his last, the stage direction tells us that vultures descend upon him that he dies with a smile, saying: "If there could have been more moments like this" (Kane, Complete Plays 103). Besides, the patient of 4.48 Psychosis once declares: "I had a night in which everything was revealed to me" (205). These words reflect upon Durkheim's view that optional altruistic suicide convinces the individual that his ego should be situated beyond life itself. The hybridity between the patient's inner darkness and the 
ambiguity of the unknown has drilled a void within her ego, a void through which she will penetrate into the afterlife happily. So, she joyfully advises herself: "Remember the light and believe the light/ An instant of clarity before eternal night" (206).

Heidi Stephenson et al. argue that suicide, for Sarah Kane, is an outlet to be familiar with the absolute. They go one step further when they maintain that Kane wants to throw a piercing light on the truth that "we have to descend to hell imaginatively to avoid going there in reality" (Stephenson et al. 133). Thus, the reader sometimes feels that the patient is nothing but a corpse which can speak. This bitter feeling is omnipresent throughout the play. The patient's preoccupation with the atrocities of the unknown seems to be the reason behind her corpse-like appearance, an appearance which forces the readers to meditate on their own nightmares about the unknown and to share the patient her own fears. Similarly, Ken Urban argues that in Kane's eyes, hell "is not metaphysical; it is hyperreal, reality magnified" (Urban 45). Consequently, with the close of the play and shortly before committing suicide, the patient worries that she "shall freeze in hell" (Kane, Complete Plays 239). It is not surprising thus that she addresses God, asking: "Dear God, dear God what shall I do? (241). This question might be taken to be a defense mechanism to free herself from the sense of guilt before committing suicide which is forbidden by divine laws. From this perspective, it can be noted that the patient has a hyperconsciousness, and this is what allows her to reject her experienced reality. Joseph Beatty labels this kind of consciousness as selfconsciousness which is a source of mighty pride or a "glory because its transcendence of all determinations" frees the individual "from diminishment and reduction" as he is "always other, he is evermore ahead of any and all of his own and others' objectifications" (Beatty 198). Beatty's argument, however, touches upon Durkheim's definition of optional altruistic suicide as the patient's ego lives its own life and obeying itself alone and regards suicide as a hope for salvation. 
In this context, the patient seems to have an underground self which can never be observed by others. The underground self is essential to self-authentication through adopting irrational behavior even if it is a point of insanity as it drives the individual into inner darkness. Seeing her life solitary, disordered, and gloomy, the patient retreats further and further into her underground corner and sink into deep, insane thoughts. The patient's underground self is in close affinity with Mikhail Bakhtin's argument about the motives behind man's desire to build up an underground self, or as he points it out: "What he fears most of all is that people might think he is repenting before someone, that he is asking someone's forgiveness, that he is reconciling himself to someone else's judgment or evaluation, that his self-affirmation is somehow in need of affirmation and recognition by another" (Bakhtin 154). As such, the therapist fails to understand that the patient has an underground self, and this failure has consecutively intensified her psychological distress. The American clinical psychologist, suicidologist and thanatologist Edwin S. Shneidman argues, "Our constant goal is prevention-but first come [sic] understanding" (Shneidman 7). Therefore, the patient kindly asks the therapist to "listen and understand, and when you feel contempt, don't express it, at least not verbally, at least not to me" (Kane, Complete Plays 220). It becomes obvious thus that the underground self of the patient is not observed even by her therapist that she asks her not to ridicule her because she is unable to observe her underground self. The following debate between the patient and the therapist highlights the patient's awareness of her underground self on the one hand and the therapist's lacking awareness of it on the other:

- Do you despise all unhappy people or is it just me?

- I don't despise you. It's not your fault. You're ill.

- I don't think so.

- No?

- No. I'm depressed. Depression is anger. It's what you did, who was there and who you're blaming. 
- And who are you blaming.

- Myself. (212, my emphasis)

Obligatory altruistic suicide is made clear through the patient's inability to cope with her psychotic disorders. When the play opens, she describes her bewildered consciousness in a way which reflects her resentment of the unbearable health conditions she bitterly experiences: "A consolidated consciousness resides in a darkened banqueting hall near the ceiling of a mind whose floor shifts as ten thousand cockroaches" (205). She appears to be so miserable throughout the play that she raises questions like "why am I stricken?" and "what am I like?" (219-239). She spends much time contemplating her mental illness, but unfortunately she is unable to be familiar with it. This recurrent meditation on insanity turns her life into a nightmare filled with uncertainty about her identity: "I don't know who I am" (226). So, she discloses her distress in a way which underlines a bitter conflict between logic and palsy, a conflict which takes the form of a sea of troubles: "Drowning in a sea of logic/ this monstrous state of palsy/ still ill" (223). She is also haunted by misery and boredom that she is always waiting for something or someone to rescue her, but in vain, and consequently she diagnoses her mental illness by herself: "I have bipolar disorder.... I am bipolar" (221). Due to her inability to cope with her mental distractions, she cries out in despair: "DON'T LET THIS KILL ME/ THIS WILL KILL ME AND CRUSH ME AND SEND ME TO HELL" (226). As a rejection of her psychological disorder, she renounces the fact that her mind "is the subject of these bewildered fragments" (210). She also cuts her arm to "relieve the tension" (216), but her attempt proves to be ineffectual.

Being unable to cope with her sickness, the patient gives voice to her desire to commit suicide through several utterances such as "I must stand alone", "fade away", and "watch me vanish" (244). Furthermore, she cannot accept the therapist's diagnosis of her case because the latter cannot touch the raw nerve which strikes all these 
fragments inside her psyche that she begins to think that the fault is hers: "It's not your fault, that's all I ever hear, it's not your fault, it's an illness, it's not your fault, I know it's not my fault. You've told me that so often. I'm beginning to think it's my fault" (220). Being unable to accept her mental illness, she proposes her plan to commit suicide this way: "Take an overdose, slash my wrists then hang myself....I'd be standing on a chair with a noose around my neck....I'm tired of life and my mind wants to die" (210). Interestingly, the patient's plan to commit suicide overshadows Kane's plan to commit suicide in the hospital in which she was medicated; the patient seemingly declares: "Everything I had/ Swallowed/ Slit/ Hung/ it is over" (242).

Technically, the stage direction of the play mirrors the unbearable fragmentation of the patient's mind and her inability to cope with her psychological disorders: "(Silence. $)$ ", "(A long silence. $)$ " or "(A very long silence.)" are frequently mentioned (217). Further, the setting of the play is reflexive of the fragmented mind of the patient who is living under unbearable health conditions: "A table two chairs and no windows / Here am I / And there is my body / dancing on glass" (230). The two chairs for one patient are indicative of a state of schizophrenia with which she cannot cope. The body which dances in the mirror is illustrative of the fact that the patient's mind is obsessed by a torrent of hallucinations. The play, however, appears to be a plethora of psycho-monologues of a patient who cannot cope with her psychotic disorders. Steve Earnest, in a theatrical review of 4.48 Psychosis, describes the play as an "internal exploration of Kane's desperate state of being" which is in conformity with the patient's state of being (Earnest 300). Clare Wallace opines that Kane's 4.48 Psychosis is "making and unmaking multiple and contradictory selves through language" (Wallace, Suspect Cultures 224). The following utterances point to a depressive and suicidal thinking which is hard to be endured ("I am sad" or "I would like to kill myself"), negative self-perception ("I am fat" or "My hips are too big"), and low self-esteem ("I am a complete failure as a 
person") (Kane, Complete Plays 206-207). Most of these utterances represent a certain confliction which is noticeable in the patient's list - "I cannot be alone" and "I cannot be with others" or "I do not want to die" and "I do not want to live" (207). This sense of inner contradiction permeates the whole play as though the patient is grappling with herself out of being unable to cope with her psychosis.

\section{Anomic Suicide}

In 4.48 Psychosis, anomic suicide is depicted through society's indifference to the patient's emotions, passions, feelings, and organic necessities as though the play is a self-reflection of Kane's suffering from the lack of love and care in her life story. In Crave, Kane makes her enigmatic character $\mathrm{C}$ speak for her to expose the negative impact of her father's visits to her in the hospital because she wants to feel emotionally like she feels physically, but her father is unable to observe her emotional necessities. C speaks for Kane, saying: "He [Kane's father] buys me a make-up kit, blushers and lipstick and eyeshadow. And I paint my face in bruises and blood and cuts and swelling, and on the mirror in deep red, UGLY" (Kane, Complete Plays 172).

Like Kane, the patient of 4.48 Psychosis complains that she can neither love nor be loved. This awareness of the disappearance of her lover and her inability to be in the company of a human other triggers a rupture of her soul: "I cannot love/ My brother is dying, my lover is dying/ I cannot fuck/ I cannot be alone/ I cannot be with others....No one touches me, no one gets near me" (207-213). The patient's anguish and her desire to commit suicide due to the lack of organic necessities in her life unfolds itself most clearly when she reveals the unbearable organic conditions under which she is living: "Not speaking, no sex drive, in despair, wants to die" (219). She overtly complains that she is "unable to reach orgasm" (220). Owing to the lack of such an essential organic necessity, she is sometimes 
haunted by hallucinations such as "a dismal whistle that is the cry of heartbreak around the hellish bowl at the ceiling of [her] mind" (222). Distressed, she confesses to her therapist that she hopes to "draw close and enjoyably reciprocate with another", "converse in a friendly manner", "tell stories", "exchange sentiments, ideas, secrets", "laugh and make jokes", "win affection of desired Other", "adhere and remain loyal to Other", "enjoy sensuous experiences with cathected Other", "form mutually enjoyable, enduring, cooperating and reciprocating relationship with Other, with an equal", "be forgiven", and "be loved" (228).

It becomes clear thus that all the patient's emotions and passions are ruthlessly repressed. However, her emotional pain is heightened when the therapist tells her that after leaving the hospital, she meets with her lover and her friends to relax, or as the therapist indifferently and unsympathetically puts it: "When I walk out of here at the end of the day I need to go home to my lover and relax. I need to be with my friends and relax" (230). Therefore, the patient vigorously blames God "for making [her] love a person who does not exist" (215), but her unshakable belief in unconditional love looms large through the following utterance: "I've always loved you/ even when I hated you" (240). The lack of an intimate relationship with a lover brings about sexual anomy, a symptom which ails her most: "I am jealous of my sleeping lover and covet his induced consciousness" (208). Sadly, she emphasizes her unquestioned faith in the value of love she has lost: "I would rather have lost my legs/ pulled out my teeth/ gouged out my eyes/ than lost my love" (230). Due to the absence of a lover, she cries out in despair: "I'm dying for one who doesn't care/ I'm dying for one who doesn't know" (243). Also, she is bitterly tormented by the disappearance of her female friend: "What does she look like? And how will I know her when I see her?" (215) Disappointed, she casts doubt on the true value of friendship, asking: "What do you offer your friends to make them so supportive?” (205). 
A Durkheimian Reading of Sarah Kane's ... Dr. Mahmoud El Bagoury

Additionally, the indifference of the therapist to the patient's feelings and passions must not go unmentioned because she takes the therapist to be Christ-like, a savior, but unfortunately she is severely disappointed by her abandonment and indifference because her view of the therapist is tantamount to a state of idolatry. She declares:

I came to you hoping to be healed.

You are my doctor, my saviour, my omnipotent judge, my priest, my god, the surgeon of my soul.

And I am your proselyte to sanity. (233)

She further blames her therapist for her indifference to her feelings because she sees that she is hospitalized "to receive attention, to be seen and heard, to excite, amaze, fascinate, shock, intrigue, amuse, entertain, or entice others" (235). The following conversation between the patient and the therapist gets the gist of the matter as it illustrates the latter's indifference to the former's haunting desire to have friends:

- You're my last hope.

- (A long silence.)

- You don't need a friend you need a doctor.

- (A long silence.)

- You are so wrong. (236)

Like the patient, Hippolytus in Kane's Phaedra's Love fails to be integrated into a human community and finds himself stuck in an anomic space in which he waits for a mysterious force to help him out to the extent that he is always "waiting...for something to happen" even if it is suicide (Kane, Complete Plays 79). So, when Strophe tells him that her mother has committed suicide, he replies: "Things are looking up" (87). 


\section{Fatalistic Suicide}

In 4.48 Psychosis, fatalistic suicide is contextualized through the patient's bitter suffering from the code of ethics of psychiatry which proves to be oppressive, overregulated, uncaring, suffocating, and fruitless. The anonymity of the therapists' names - "Dr This and Dr That and Dr Whatsit" (209) —who are an integral part of the psychiatric medical system is indicative of an overregulated system which is indifferent to the fragmentation of individuals with psychological disorders. This lethal overregulation is highlighted when the patient hurls a barrage of insults at the medical health care system represented by the therapist "who lied. And said it was nice to see me. I trusted you, I loved you, and it's not losing you that hurts me, but your bare-faced fucking falsehoods that masquerade as medical notes" (210). Instead of delving deeply into the patient's psyche to recognize the psychotic disorders which rupture her soul, the therapist unscrupulously pushes her towards a bitter sense of guilt.

For instance, when the patient cuts her arm to relieve the tension, the therapist's comment on this action indicates sarcasm rather than sympathy: "Did it relieve the tension?" (216) She also scolds the patient for allowing herself to fall prey to a futile existence, for "allowing this state of desperate absurdity" (237). Even when the patient tells the therapist that she needs a friend more than she needs a therapist, the latter indifferently replies that therapists accept sane friends only: "I need my friends to be sane" (237). Herein, Kane directs a scathing satire against the concept of sanity adopted by society. After an examination of the patient's state of mind, the therapist provides the following definition of sanity: "Sanity is found at the centre of convulsion, where madness is scorched from the bisected soul" (233). By contrast, Kane provides the following definition of sanity in the play - a definition which is at poles apart with what she calls "the chronic insanity of the sane"- "Sanity is found in the mountain of the Lord's house on the horizon of the soul 
Dr. Mahmoud El Bagoury

that eternally recedes" (206). So, Ariel Watson rightly argues that 4.48 Psychosis portrays the psychiatric methodologies as "tools for the manipulation and objectification... of the patient" (Watson 189). Following Watson's argument, the patient complains: "I really feel like I'm being manipulated" (215), a feeling which forces her to give voice to her paranoid fears that "hospital staff are attempting to poison her" (Kane, Complete Plays 223).

Moreover, the patient's resentment of the humiliation and uselessness of the psychiatric system comes into full play when she states that all she has gained from being hospitalized is nothing but an intensifying sense of dismay and ridicule which forces her to come to the conclusion that all attempts to be healed are doomed that she begins to regard her life as no longer worth living: "Burning in a hot tunnel of dismay, my humiliation complete as I shake without reason and stumble over words and have nothing to say about my 'illness' which anyway amounts only to knowing there's no point in anything because I'm going to die" (209). Regarding psychiatry as a failure, she asks the therapist not to deride her while she is speaking about her psychological disorders. Perhaps Kane wants to mock the therapist for not knowing the significance of the talking-cure healing mechanism in psychiatry. Consequently, the patient satirically comments on the failure of the standardization and overregulation of the mainstream which overregulates the medical system: "Despair propels me to suicide/ Anguish for which doctors can find no cure/ No care to understand" (239).

So fed up with the suffocating discipline of the medical system, the patient hurls a barrage of accusations at the therapist by telling her that she is hospitalized not to be blamed or even ridiculed, but rather to "increase self-regard", "defend my psychological space", "vindicate the ego", "receive attention", "be free from social restrictions", "resist coercion and constriction", "avoid pain", "avoid shame", "obliterate past humiliation", "maintain self-respect", "repress fear", and "overcome weakness" (236). In a similar vein, 
the patient's dissatisfaction with the oppressive psychiatric system in 4.48 Psychosis recalls the dissatisfaction of the enigmatic character $\mathrm{M}$ in Kane's Crave. The following words envisage M's phobia of growing old in a hospital which is overregulated by a purely capitalistic system: "I don't want to be living in a bedsit at sixty, too sacred to turn the heater on because I cannot pay the bill" (Kane, Complete Plays 165).

\section{Conclusion}

To conclude, Kane's 4.48 Psychosis encompasses the four kinds of suicide proposed by Durkheim: egoistic suicide, altruistic suicide, anomic suicide, and fatalistic suicide. This cluster of intertwined forms of suicide is recurrent throughout the play, and suicide proves to be the omnipresent theme of the play. These forms are contextualized through delving deeply into the troubled mind and soul of the depressed patient, her blurred view to life, her distorted patterns of relationship with society and others, and her hopelessness resulting from the oppressive overregulation of the medical system represented by her therapist.

Egoistic suicide is made clear through the patient's fragmented ego that she is haunted by a blurred vision of life. She feels that she is trapped into a minimal existence in a chaotic world. Her broken view of life throws her into a state of egoism and an existential void, a void in which she loses her identity. She is also haunted by a sense of guilt and self-condemnation out of feeling she is living in the wrong place. Her divided ego also forces her to dislike her body and her soul. So, she regards suicide as an appropriate medium to do away with all these imperfect visions to come closer to an objective reality in which her body and soul can be united to touch her essential self.

Optional altruistic suicide is depicted through the patient's view of suicide as a window overlooking infinity which is filled with 
clarity, euphoria, and nirvana. Thus, she thinks that she should be situated beyond life itself to penetrate the world of the unknown voluntarily by committing suicide. Obligatory altruistic suicide is demonstrated through the patient's inability to cope with her psychotic disorders. She is unable to be harmonious with her bewildered consciousness that she always contemplates her mental illness, a contemplation which turns her life into a nightmare replete with hysterical intrusions, delusions, and hallucinations which force her to think that the proper solution to dispose of all these distressing symptoms is to kill herself.

Anomic suicide comes to light through the patient's personal unrest, frustration, boredom, and anomy due to the lack of love, care, intimacy, and all organic necessities. The therapist's nonchalance to her feelings and passions has much heightened her anomy and distress. Due to the lack of unconditional love, friendship, and sexual intercourse, she feels that her life is no longer worth living and that suicide is a medium which will provide a release from these anomic feelings.

Fatalistic suicide is contextualized through the patient's dismay at the failure of the medical system to find a cure for her, a system which proves to be oppressive and sarcastic rather than understanding and caring. The patient feels she is manipulated and objectified in the hospital moving from one chamber to another with no cure or even sympathy from the medical staff that she becomes so desperate and depressed with the passage of time till she commits suicide with the close of the play. 


\section{References}

Artaud, Antonin. The Theatre and its Double. $3^{\text {rd }}$ Edition. Trans. Victor Corti. London: John Calder, 1977.

Bakhtin, Mikhail. "Discourse in Dostoevsky." Notes from Underground: A Norton Critical Edition. Trans. and ed. Michael R. Katz. New York: Norton, 1989.152-162.

Beatty, Joseph. "From Rebellion and Alienation to Salutary Freedom: A Study in Notes from Underground." Soundings 61 (1987): 182-205.

Butler, Judith. Undoing Gender. London: Routledge, 2004.

Carney, Sean. "The Tragedy of History in Sarah Kane's Blasted." Theatre Survey 46.2 (November 2005): 275-269.

Durkheim, Emile. Suicide: A Study in Sociology. Trans. John A. Spaulding and George Simpson. London and New York: Routledge, 2005.

Earnest, Steve. "4.48 Psychosis (Review)." Theatre Journal 57.2 (2005): 298-300.

Freud, Sigmund. Beyond the Pleasure Principle. Trans. James Starchey. New York; London: W. W. Norton \& Company, 1961.

Jameson, Frederic. "Postmodernism and Consumer Society." The Anti-Aesthetic: Essays on Postmodern Culture. Ed. Hal Foster. Seattle: Bay, 1983.

Kane, Sarah. Complete Plays. London: Methuen, 2001.

---. "Interview by Dan Rebellato." Royal Holloway University of London Press. 3 November 1998. 1-19.

Lacan, Jacques. "The Mirror Stage as Formative of the Function as Revealed in Psychoanalytic Experience." Ecrits: A Selection.

Trans. Bruce Fink. New York: Norton, 2002. 3-9.

Nadeau, Maurice. "Samuel Beckett: Humor and the Void." Samuel Beckett: A Collection of Critical Essays. Ed. Martin Esslin. Englewood Cliffs, N. J.: Prentice-Hall, 1987.

Saunders, Graham. "Love Me or Kill Me." Sarah Kane and the Theatre of Extremes. Manchester: Manchester UP, 2002. 
A Durkheimian Reading of Sarah Kane's ... Dr. Mahmoud El Bagoury

Selby, Edward A., Thomas E. Joiner, Jr., and Jessica D. Ribeiro. "Comprehensive Theories of Suicidal Behaviors." The Oxford Handbook of Suicide and Self-injury. Ed. Mathew K. Nock. Oxford UP, 2014.

Shneidman, Edwin S. The Suicidal Mind. New York: Faber \& Faber Plays, 2009.

Sierz, Aleks, ed. In-Yer-Face Theatre: British Drama Today. London: Faber and Faber, 2001.

---. "Sarah Kane." In-Yer-Face Theatre: British Drama Today. London: Faber and Faber, 2001. 90-121.

---. The Theatre of Martin Crimp. London: A. C. Black, 2006.

Singer, Annabelle. "Don't Want to Be This: The Elusive Sarah Kane." TDR/The Drama Review 48.2 (2004): 139-171.

Stephenson, Heidi, and Natasha Langridge. Rage and Reason: Women Playwrights on Playwriting. London: Methuen, 2007.

Urban, Ken. "An Ethics of Catastrophe: The Theatre of Sarah Kane." PAJ: A Journal of Performance and Art 23.3 (2001): 36-46.

Wallace, Clare. "Sarah Kane: Experiential Theatre and the Revenant Avant-Grade." Sarah Kane in Context. Eds. Laurens De Vos and Graham Saunders. Manchester: Manchester UP, 2010.

---. Suspect Cultures: Narrative, Identity and Citation in 1990s New Drama. Praha: Litteraria Pragensia, 2006.

Watson, Ariel. "Cries of Fire: Psychotherapy in Contemporary British and Irish Drama." Modern Drama 51.2 (2008): 188210. 